\title{
CORRIGENDUM
}

\section{Biological aspects of silky shark Carcharhinus falciformis in the eastern Arabian Sea - CORRIGENDUM}

SIJO P. VARGHESE, D.K. GULATI, N. UNNIKRISHNAN AND A.E. AYOOB

doi: 10.1017/Soo25315415001575, Published by Cambridge University Press, first published online 21 October 2015

Where it is read in the published text (p. 8, Table 4, last row)

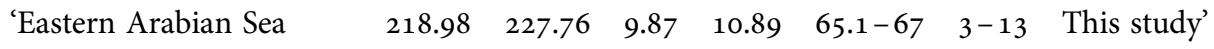

it should instead read:

$\begin{array}{llllllll}\text { Eastern Arabian Sea } & 217.0 & 226.5 & 9.66 & 10.74 & 65.1-67 & 3-13 & \text { This study }\end{array}$

The authors regret this error.

REFERENCE

Varghese S.P., Gulati D.K., Unnikrishnan N. and Ayoob A.E. (2015) Biological aspects of silky shark Carcharhinus falciformis in the eastern Arabian Sea. Journal of the Marine Biological Association of the United Kingdom, available on CJO2015. doi:10.1017/So025315415001575. 